\title{
PROGRAM JOGJA SMART CITY DALAM MENINGKATKAN PELAYANAN PUBLIK BERBASIS SOSIO-KULTURAL
}

\author{
Bambang Sektiawan Wibisono \& Sigit Handoko \\ Universitas PGRI Yogyakarta \\ bambangwibisono@gmail.com
}

\begin{abstract}
Abstrak
Penelitian Kualitatif ini bertujuan untuk mengetahui pemerintah mengimplementasikan Jogja Smart City tersebut di Kota Yogyakarta dalam meningkatkan pelayanan publik berbasis sosio-kultural. Metode penelitian ini menggunakan metode penelitian kualitatif deskriptif. Tempat penelitian Dinas Komunikasi, Informatika dan Persandian Kota Yogyakarta. Subjek penelitian adalah Kepala Bidang Sie Smart City, Pranata Komputer. Teknik pengumpulan data yang dilakukan adalah observasi, wawancara, dokumentasi. Teknik analisis data dengan cara mereduksi data atau meringkas data yang diperoleh, kemudian dengan menyajikan data yang mempunyai hubungan dengan judul. Keabsahan data menggunakan triangulasi sumber dan triangulasi teknik pengumpulan data. Berdasarkan hasil penelitian dapat disimpulkan bahwa Implementasi program Jogja smart city di Kota Yoggyakarta dalam meningkatkan pelayanan publik berbasis sosio- kultural sudah berjalan dengan baik. Pelaksanaan smart city di Kota Yogyakarta sangat didukung oleh Pemerintah dengan berbagai macam fasilitas penunjang seperti penyediaan wifi di 100 titik poin. Hal ini bertujuan untuk mengenalkan terlebih dahulu bahwa dengan perkembangan teknologi smart city masyarakat Kota Yogyakarta akan lebih mudah, lebih cepat dan sangat efisien dalam pengurusan yang terkait dengan pemerintahan. Pemerintah Kota Yogyakarta juga memanfaatkan smart city untuk pembangunan yang berkelanjutan tanpa meninggalkan image Kota Yogyakarta sebagai Kota Wisata, Kota Budaya dan Kota Pelajar. Hal ini dilihat dari menu layanan yang terdapat di dalam Jogja Smart Service yang sudah mencakup tentang informasi wisata, budaya dan pelajar.
\end{abstract}

Kata Kunci: Smart City, Pelayanan Publik, Sosio-kultural

\begin{abstract}
This research method uses descriptive qualitative research methods. The research site of the Yogyakarta City Communication, Informatics and Encoding Agency. The subject of the research was the Head of Sie Smart City, Computer Institution. Data collection techniques used were observation, interviews, documentation. Data analysis techniques by reducing data or summarizing the data obtained, then by presenting data that has a relationship with the title. Data validity uses source triangulation and data collection technique triangulation. Based on the results of the study it can be concluded that the implementation of the Jogja smart city program in the City of Yogyakarta in improving socio-culturalbased public services has been going well. The implementation of smart city in the city of Yogyakarta is strongly supported by the Government with various supporting facilities such as providing wifi at 100 points. This aims to introduce in advance that with the development of smart city community technology, Yogyakarta City will be easier, faster and very efficient in management related to government. The Government of Yogyakarta City also utilizes smart cities for sustainable development without leaving the image of Yogyakarta City as a Tourist City, Cultural City and Student City. This can be seen from the service menu contained in Jogja Smart Service which includes information on tourism, culture and students.
\end{abstract}

Keywords: Smart City, Public Services, Socio-cultural

PENDAHULUAN

Perkembangan ilmu dan teknologi yang semakin pesat, masyarakat perlu mengikuti perkembangan IPTEK 
tersebut, apabila masyarakat/individu tidak mau atau tidak mampu mengikuti maka akan mengalami ketertinggalan dalam kemajuan zaman, untuk mengejar ketertinggalan di dalam kemajuan zaman pemerintah berusaha untuk memfasilitasi guna mendukung masyarakatnya agar menjadi masyarakat yang lebih maju dan modern (Binti Maunah, 2009:5). Akses internet seperti media sosial merupakan satu dari sekian banyak contoh semakin berkembangnya teknologi (Nurgiansah, 2019).

Konsep Smart City muncul sebagai tuntutan perlunya membangun identitas kota yang layak huni, aman, nyaman, hijau, berketahanan iklim dan bencana, berbasis pada karakter fisik, keunggulan ekonomi, budaya lokal, berdaya saing, berbasis teknologi dan IT. Pemerintah pusat telah meluncurkan Indeks Kota Cerdas Indonesia 2015 yang bertujuan menilai dan mengapresiasi sejumlah kota di Indonesia yang telah menerapkan konsep tersebut. Dalam konsep solusi Smart City ini, pemerintah, industri, akademis, maupun masyarakat ikut terlibat untuk menjadikan kota menjadi lebih baik.

Tujuan implementasi Smart City adalah untuk dapat membentuk dan menerapkan suatu kota yang aman, nyaman, terkendali dan mempermudah akses bagi warganya serta memperkuat daya saing kota dalam hal perekonomian, sosial dan teknologi. Dijelaskan bahwa tujuan dari strategi implementasi Smart City adalah untuk menunjang kota di dalam dimensi sosial (keamanan), ekonomi (daya saing), teknologi dan lingkungan (kenyamanan). Atau lebih umum lagi berdasarkan United Nation, dapat dikatakan bahwa tujuan Smart City adalah untuk membentuk kota yang Sustainable (ekonomi, sosial, lingkungan). Secara umum pelaksanaan konsep smart city ini juga sudah mulai berjalan dengan dukungan aplikasi yang terus berkembang sehingga tercipta lingkungan yang kreatif di bidang teknologi, sebagai langkah awal yang baik menuju kota pintar.

Beberapa kota di Indonesia telah memiliki aplikasi sebagai panduan destinasi kota, salah satunya Daerah Istimewa Yogyakarta. Daerah Istimewa Yogyakarta, dikenal sebagai daerah yang memiliki banyak sumber daya wisata. Di sisi lain, perkembangan teknologi membuat internet memberi banyak variasi informasi. Pemerintah D.I. Yogyakarta telah mengintegrasikan informasi-informasi publik di wilayah D.I. Yogyakarta. Aplikasi ini memanfaatkan teknologi smartphone yang digunakan oleh seluruh masyarakat untuk mempermudah dalam penyampaian informasi.

Perkembangan teknologi informasi dan komunikasi berupa mobile phone dan smartphone dianggap lebih efektif dalam mempublikasikan potensi pariwisata. Integrasi informasi publik ini diharapkan pemanfaatannya dapat mempermudah masyarakat dalam perolehan informasi yang akurat. Tujuan adanya aplikasi ini untuk mempermudah masyarakat dan wisatawan dalam memperoleh informasi tentang D.I. Yogyakarta secara tepat, cepat, dan aktual.

Yogyakarta memiliki kekayaan budaya yang tak hilang oleh perubahan jaman, modal sosial dan kecerdasan lokal serta modal insani, kreatif inovatif dan toleransi tinggi. Jogja juga dikenal sebagai kota yang nyaman untuk ditinggali disamping itu Yogyakarta juga sering dianggap sebagai Indonesia mini karena mahasiswa datang dari penjuru 
nusantara dengan berbagai adat istiadat mereka yang dapat menyatu dengan budaya masyarakat Jogja yang memang dikenal ramah dan terbuka kepada pendatang serta keberadaan Sultan sebagai panutan dan dinamika politik yang relatif stabil hingga saat ini. Program Jogja smart city ini masih belum terrealisasikan dengan baik masih banyak persoalan yang pemerintah hadapi dalam mengimplementasikannya.

\section{METODE PENELITIAN}

Pendekatan deskriptif kualitatif untuk memperoleh gambaran yang bersifat komprehensif dan mendalam tentang Implementasi Program Jogja Smart city Di Kota Yogyakarta Dalam Meningkatkan Pleayanan Publik Berbasis Sosio- kultural. Teknik pengumpulan data dan informasi dari informan menggunakan metode observasi, dokumentasi, dan wawancara. Responden dalam penelitian ini berjumlah 5 orang, yaitu 1 orang kepala Sie. Pengembangan Smart City, 1 orang sebagai pranata komputer, 3 orang yaitu masyarakat pengguna layanan. Penelitian ini juga menggunakan teknik dokumentasi yaitu dengan cara pengambilan gambar atau foto pada hal-hal yang dilakukan oleh peneliti pada saat penelitian. Teknik analisis data yang digunakan dalam penelitian ini yaitu reduksi data, data display (penyajian data), dan conclusion drawing/ verification.

\section{HASIL PENELITIAN DAN PEMBAHASAN Hasil Penelitian}

Mazamanian dan Sabatier mendefinisikan arti implementasi sebagai pelaksanaan dari sebuah kebijakan dasar dari hukum yang juga bisa diterapkan dalam pemerintahan maupun dalam hal putusan pengadilan.
Pelaksanaan dalam konteks ini, maksudnya dalam bidang hukum, bukan terjadi secara spontan atau tibatiba. Ada proses yang harus dijalankan sebelum implementasi dalam konteks ini benar-benar akan dijalankan. Tahapan-tahapan yang harus dilalui seperti tahap mengesahkan undangundang, kemudian dilanjutkan dengan adanya ouput. Output ini berupa pelaksanaan atas keputusan maupun kebijakan yang sudah ditentukan.

Studi implementasi merupakan suatu kajian mengenai studi kebijakan yang mengarah pada proses pelaksanaan dari suatu kebijakan. Dalam prakteknya implementasi kebijakan merupakan suatu proses yang begitu kompleks bahkan tidak jarang bermuatan politis dengan adanya intervensi berbagai kepentingan. Bardach yang dikutip oleh Agustino (2006:138) dalam bukunya "DasarDasar Kebijakan Publik" sebagai berikut: "implementasi adalah cukup untuk membuat sebuah program dan kebijakan umum yang kelihatannya bagus diatas kertas. Lebih sulit lagi merumuskannya dengan kata- kata dan slogan-slogan yang kedengarannnya mengenakan bagi telinga para pemimpin dan para pemilih yang mendengarkannya.

Dan lebih sulit lagi untuk melaksanakannya dalam bentuk cara yang memuaskan semua orang termasuk mereka anggap klien. "Perlu dicatat bahwa implementasi kebijakan merupakan tahapan yang sangat penting dalam struktur kebijakan, karena melalui prosedur ini proses kebijakan secara keseluruhan dapat dipengaruhi tingakat keberhasilan atau tidaknyapencapaian tujuan.

Smart City atau secara harafiah berarti kota pintar, merupakan suatu konsep pengembangan, penerapan, 
dan implementasi teknologi yang diterapkan untuk suatu wilayah sebagai sebuah interaksi yang kompleks di antara berbagai sistem yang ada di dalamnya. Disini digunakan kata City (kota) untuk merujuk kepada kota sebagai pusat dari sebuah negara atau wilayah, dimana semua pusat kehidupan berada (pemerintahan, perdagangan, pendidikan, kesehatan, pertanahan, dan lain-lain). Demikian pula dengan pusat pemukiman penduduk, dimana jumlah penduduk di kota relatif jauh lebih banyak dibandingkan wilayah lainnya (misalnya desa/sub kota). Kota menjadi daya tarik orang untuk menetap. Di Indonesia sendiri, urbanisasi mengacu kepada proses perpindahan masyarakat dari desa ke kota untuk memperoleh penghidupan (kerja) maupun pendidikan (I Putu Agus Eka Pratama. 2014).

Definisi atau pengertian Smart City sangat beraneka ragam. Konsep tersebut sudah dikenal dengan populer, namun dalam prakteknya digunakan di berbagai negara dengan istilah yang berbeda-beda dan situasi yang berbeda pula. Ada penggunaan berbagai jenis konsep mengganti smart dengan istilah kata sifat lainnya.

Smart city adalah visi pembangunan perkotaan untuk mengintegrasikan beberapa teknologi informasi dan komunikasi (ICT) dan solusi Internet of Things (IOT) dalam sebuah bentuk yang aman untuk mengelola aset kota. Berdasarkan Wikipedia, definisi dari Smart City itu begitu luas mencakup berbagai macam keseluruhan teknologi digital yang dapat meningkatkan kualitas kehidupan, mengurangi biaya dan sumber konsumsi, dan dapat meningkatkan interaksi aktif antara kota dan warganya secara efektif.
Deakin mendefinisikan kota pintar sebagai salah satu yang memanfaatkan ICT untuk memenuhi tuntutan pasar (warga kota), dan bahwa keterlibatan masyarakat dalam proses ini diperlukan untuk sebuah kota pintar. Sehingga Kota cerdas akan menjadi kota yang tidak hanya memiliki teknologi ICT di daerah tertentu, tetapi juga telah menerapkan teknologi ini dengan cara yang positif berdampak pada masyarakat setempat.

Smart City merupakan sebuah visi pengembangan perkotaan untuk mengintegrasikan teknologi informasi dan komunikasi (TIK) dan teknologi Internet of things (IoT) dengan cara yang aman untuk mengelola aset kota. Aset ini meliputi sistem informasi instansipemerintahan lokal, sekolah, perpustakaan, sistem transportasi, rumah sakit, pembangkit listrik, jaringan penyediaan air, pengelolaan limbah, penegakan hukum, dan pelayanan masyarakat lainnya. ditujukan dalam hal penggunaan informatika dan teknologi perkotaan untuk meningkatkan efisiensi pelayanan.

TIK memungkinkan para pejabat kota berinteraksi langsung dengan masyarakat dan infrastruktur kota serta memantau apa yang terjadi di kota, bagaimana kota berkembang, dan bagaimana menciptakan kualitas hidup yang lebih baik. Melalui penggunaan sensor yang terintegrasi dengan realtime monitoring sistem, data yang dikumpulkan dari warga dan perangkat kemudian diolah dan dianalisis. Informasi dan pengetahuan yang dikumpulkan adalah kunci untuk mengatasi permasalahan yang sedang dilaporkan atau terjadi.

Smart City juga merupakan kota atau bisa disebut dengan kota yang lebih modern dengan perkembangan teknologi yang cukup pesat, 
mengintregasikan teknologi informasi dan komunikasi sehingga dapat membangun tata kelola kota yang efisiensi dan baik sehingga bisa meningkatkan kesejahteraan bagi warga. Banyaknya populasi smartphone di era modern ini membuat banyak sekali orang tertarik untuk membelinya sehingga tidak dipungkiri bahwa setiap kita di jalan pasti melihat banyak orang yang menggunakan smartphone, dengan banyaknya masyarakat yang memilikinya muncullah ide atau gagasan dari berbagai kalangan sehingga sekarang banyak orang berlomba-lomba untuk membuat aplikasi, dengan gemarnya masyarakat dengan smartphone sehingga pemerintah membuat trobosan aplikasi yang berbasis android melalui smartphone sehingga semua kalangan dapat menggunakannya, dengan adanya aplikasi jogja smart city masyarakat dapat menikmati layanan publik, dan pelayanan lainnya secara mudah hanya melalui smartphone saja.

Pelayanan Publik Berdasarkan Undang-undang Republik Indonesia pasal 1 nomor 25 tahun 2009 tentang Pelayanan Publik, pelayanan publik adalah kegiatan atau rangkaian kegiatan dalam rangka pemenuhan kebutuhan pelayanan sesuai dengan peraturan perundang-undangan bagi setiap warga negara dan penduduk atas jasa, barang, dan/atau pelayanan administratif yang disediakan oleh penyelenggara pelayanan publik.

Menurut Keputusan Menteri Pendayagunaan Aparatur Negara No.63 /KEP/M.PAN/7/2003, pelayanan publik adalah segala kegiatan pelayanan yang dilaksanakan oleh penyelenggara pelayanan publik sebagai upaya pemenuhan kebutuhan penerima pelayanan maupun pelaksanaan ketentuan peraturan perundangundangan. Dan selanjutnya menurut Ridwan dan Sudrajat (2009:19) pelayanan publik merupakan pelayanan yang diberikan oleh pemerintah sebagai penyelenggara negara terhadap masyarakatnya guna memenuhi kebutuhan dari masyarakat itu sendiri dan memiliki tujuan untuk meningkatkan kesejahteraan masyarakat.

Dengan demikian, berdasarkan uraian yang dibahas di atas dapat disimpulkan bahwa pelayanan publik adalah proses pemenuhan keinginan dan kebutuhan masyarakat oleh penyelenggaraan negara dalam hal ini negara didirikan oleh publik (masyarakat) tentu saja dengan tujuan agar dapat meningkatkan kesejahteraan masyarakat. Pada hakekatnya negara dalam hal ini pemerintah haruslah dapat memenuhi kebutuhan masyarakat. Kebutuhan ini harus dipahami bukanlah kebutuhan secara individual akan tetapi berbagai kebutuhan yang sesungguhnya diharapkan oleh masyarakat.

Menentukan kualitas layanan publik perlu dilakukan uji dan analisa lebih mendalam. Kualitas pelayanan merupakan perbandingan antara kenyataan atas pelayanan yang diterima dengan harapan atas pelayanan yang ingin diterima. Dalam mengevaluasi kualitas pelayanan tidak hanya ditentukan oleh pemerintah saja namun juga ditentukan oleh masyarakat. Untuk mengukur kualitas pelayanan, ukurannya bukan hanya ditentukan oleh pihak yang melayani saja tapi lebih banyak dilayani, karena merekalah yang menikmati layanan sehingga dapat mengukur kualitas pelayanan beradasarkan harapanharapan mereka dalam memenuhi kepuasannya. 
Ainul Yaqin (2005: 6) berpendapat bahwa "budaya adalah sesuatu yang general dan spesifik sekaligus". General dalam hal ini berarti setiap manusia di dunia ini mempunyai budaya, sedangkan spesifik berarti setiap budaya pada kelompok masyarakat adalah bervariasi antara satu dan lainnya. Sedangkan Tylor dalam H.A.R Tilaar (2002: 39) berpendapat bahwa "Budaya atau peradaban adalah suatu keseluruhan yang kompleks dari pengetahuan, kepercayaan, seni, moral, hukum, adat istiadat, serta kemampuaan kemampuan dan kebiasaan lainnya yang diperoleh manusia sebagai anggota masyarakat".

H.A.R Tilaar (2002: 41) sendiri berpendapat bahwa kebudayaan merupakan suatu proses pemanusiaan yang artinya di dalam kehidupan berbudaya terjadi perubahan, perkembangan dan motivasi. Pentingnya kebudayaan dalam kehidupan manusia inilah yang kemudian mendasari bahwa kebudayaan tidak bisa dilepaskan dari pendidikan. Melihat kondisi bangsa Indonesia yang terdiri dari berbagai budaya.

\section{Pembahasan}

Smart city merupakan wilayah kota yang telah mengintegrasikan teknologi informasi dan komunikasi dalam tata kelola sehari-hari. Smart city memiliki tujuan untuk mempertinggi efisiensi, memperbaiki pelayanan publik, dan meningkatkan kesejahteraan warga. Integrasi teknologi dalam tata kelola kota dimungkinkan berkat keberadaan internet of things, yaitu jaringan perangkat elektronik yang saling terhubung dan mampu mengirim data ataupun melakukan tindak lanjut dengan campur tangan manusia yang minimal. Implementasi smart city di Indonesia sendiri mengalami berbagai kendala, mulai dari infrastruktur penunjang yang belum memadai, kesiapan pemerintah setempat, hingga masyarakat sendiri yang belum mampu memanfaatkan teknologi digital secara maksimal.

Kementerian Komunikasi dan Informatika (Kemkominfo) menyatakan komitmen untuk mendukung pengembangan smart city di Indonesia. Pemerintah pusat mencanangkan program 100 Smart City yang merupakan program bersama Kementerian Komunikasi dan Informatika, Kementerian Dalam Negeri, Kementerian PUPR, Bappenas dan Kantor Staf Kepresidenan. Menteri Komunikasi dan Informatika (Menkominfo) Rudiantara menyebutkan bahwa di Indonesia terdapat 514 kabupaten/kota. Dengan jumlah sebanyak itu, maka pengembangan smart city di daerah harus mempertimbangkan penganggaran secara matang apakah mampu bertahan memenuhi kebutuhan anggaran dalam membangun smart city.

Di Indonesia, beberapa kota besar sudah mulai mengadopsi konsep smart city. Ibukota Jakarta memulai program Jakarta Smart City sejak tahun 2014. Kota Surabaya juga terus menerapkan inovasi guna menjadi smart city, misalnya dengan menerapkan sistem tilang online bagi pengemudi kendaraan bermotoryang melakukan pelanggaran lalu lintas. Kota Yogyakarta memulai program smart city sejak tahun 2018 dengan diluncurkannya aplikasi Jogja Smart City.

Smart city di Kota Yogyakarta dilaksanakan berdasarkan masterplan yang sudah disiapkan oleh Dinas 
Komunikasi, Informasi dan Persandian Kota Yogyakarta. Pelaksanaan smart city di Kota Yogyakarta berawal dari keinginan Pemerintah Kota Yogyakarta untuk mendorong peran aktif dan masyarakat Kota Yogyakarta dalam pengelolaan kota menjadi kota yang efisiensi, ramah dan mudah diakses oleh semua kalangan. Hal ini sejalan dengan aspek utama pembangunan smart city yaitu smart governance, smart technology, smart infrastructure, smart healthcare, smart mobility, smart building, smart energy dan smart citizen. Tujuan dari smart city itu sendiri adalah untuk membentuk suatu kota yang nyaman, aman, serta memperkuat daya saing dalam perekonomian.

Pemanfaatan teknologi informasi saat ini tidak lagi digunakan dalam sebuah PC maupun smartphone pribadi, namun sudah menjangkau ranah pemerintahan. Smart city dikenal karena pelayanan perkotaan yang dilakukan dengan memanfaatkan peran teknologi informasi. Smart city juga menjadi salah satu penopang utama bagi penciptaan good governance. Konsep smart city kini mulai diterapkan dan menjadi dambaan semua kota di Indonesia. Di Kota Yogyakarta pelaksanaan smart city tidak hanya melalui aplikasi. Pemerintah Kota Yogyakarta sudah menerapkan smart city pada instansi Unit Kerja di Pemerintahan yang juga merupakan bentuk sosialisasi smart city kepada masyarakat agar melek teknologi.

Ketidaksamaan konsep smart city sesungguhnya. Pasalnya, sejauh ini belum ada pengaturan langsung terkait smart city. Selama ini pemerintah daerah masih menggunakan peraturan yang terkait saja dengan smart city misalnya UU No 25 Tahun 2004 tentang Sistem Perencanaan Pembangunan Nasional, UU
No 11 tahun 2008 tentang Informasi dan Transaksi Elektronik, UU No 14 Tahun 2008 tentang Keterbukaan Informasi Publik, UU No 25 tahun 2009 tentang Pelayanan Publik, dan UU No 23 tahun 2014 tentang Pemerintahan Daerah.

Penerapan smart city harus sinergis dengan kondisi sosio- kultural yang ada di Kota Yogyakarta, smart city diharapkan tidak hanya adopsi teknologi, namun juga diharapkan mampu menjadi cerdas tanpa meninggalkan kearifan lokal. Untuk mewujudkan smart city diperlukan suatu kolaborasi yang menghimpun berbagai stakeholder, baik dari industri, pemerintah, pendidikan, komunitas maupun masyarakat. Yogyakarta adalah kota yang menghubungkan antara kebutuhan dan persediaan.

Hal ini merupakan tantangan bagi Kota Yogyakarta untuk menjadi industri yang harus memiliki platform yang kuat. Penyusunan smart city di Kota Yogyakarta tidak lepas dari konsep smart city versi Yogyakarta yang terdiri dari empat kata kunci utama yang dielaborasikan, yaitu pendidikan, pariwisata, budaya, dan pusat pelayanan jasa. Urgensi yang sangat terlihat adalah persamaan persepsi kepada seluruh Kepala OPD dan Unit Kerja di Pemerintah Kota untuk bisa memahami tuntutan bahwa semua elemen Pemkot harus aktif terlibat dalam proses kerja pengembangan smart city di Yogyakarta.

Konsep smart city harus memberikan manfaat dan dirasakan dampaknya ke masyarakat. Pemerintah Kota Yogyakarta sudah memiliki layanan terpadu terkait publik, aduan, informasi berbasis website dan aplikasi android Jogja Smart Service. Untuk mendorong dan mengevaluasi penerapan Jogja Smart Service, OPD Pemerintah Kota 
Yogyakarta melaksanakan penilaian dan evaluasi. Hal ini sejalan dengan pernyataan Wakil Walikota Yogyakarta Heroe Poerwadi yang mengatakan bahwa rangkaian penilaian evaluasi dan penilaian merupakan kegiatan yang dilaksanakan untuk memberikan apresisi kepada OPD dan kelompok masyarakat yang mengembangkan smart city. Penilaian dan evalusi smart city yang dilaksanakan mengacu pada 6 hal dalam konsep smart city yakni pemerintah, ekonomi, branding atau pemasaran, transportasi, lingkungan, kehidupan bermasyarakat.

Pelaksanaan smart city tidak hanya berfokus pada teknologi tetapi juga unsur sosial dan kultural yang sudah berjalan. Dinas Komunikasi Informasi dan Persandian Kota Yogyakarta menyatakan bahwa lingkup pelaksanaan smart city berdasarkan teknologi berada di bawah naungan Dinas Komunikasi Informasi dan Persandian Kota Yogyakarta. Smart city bertujuan untuk mensejahterakan warga. Smart city menjadikan Kota Yogyakartamenjadi kota yang nyaman, kota yang ramah anak, kota yang mensejahterakan masyarakat secara lahir dengan meningkatkan tingkat perekonomian minimal mengurangi pengeluaran. Sekarang ini sudah banyak tersedia layanan online yang efeknya masyarakat menjadi sehat, pengeluarannya berkurang, penggunaan energy yang diminimalkan, keselamatan masyarakat mengalami peningkatan, sehingga angka kecelakaan turun dan mengurangi polusi di lingkungan.

Tentunya dalam pelaksanaan terdapat berbagai macam rintangan yang menghalangi pelaksanaan konsep smart city melalui aplikasi "Jogja Smart Service" ini. Hambatan yang terlihat adalah kurangnya koordinasi antara
Pemerintah Kota Yogyakarta dengan pemerintah provinsi maupun kabupaten, kurangnya perhatian masyarakat terhadap aplikasi tersebut. namun hambatan tersebut seiring berjalanya waktu akan dicoba diatasi oleh Pemerintah Kota Yogyakarta guna memaksimalkan potensi penggunaan konsep smart city di Kota Yogyakarta. Eksistensi "Jogja Smart Service" pada kalangan masyarakat Kota Yogyakarta belum dapat dikatakan setara dengan keberadaan forum "Info Cegatan Jogja". Namun demikian bukan tidak mungkin jika pada suatu saat nanti aplikasi "Jogja Smart Service" dapat berkembang menjadi suatu aplikasi yang sepenuhnya eksis dan sepenuhnya dapat dimanfaatkan oleh masyarakat Kota Yogyakarta dikarenakan perkembangan teknologi akan semakin maju sehingga masyarakat dituntut untuk terus bergerak kedepan.

\section{KESIMPULAN}

Implementasi program Jogja smart city di Kota Yogyakarta dalam meningkatkan pelayanan publik berbasis sosio- kultural sudah bisa dikatakan meningkat dilihat dari banyaknya masyarakat yang cukup antusias mendownload aplikasi Jogja Smart Service, serta masyarakat sudah merasakan dampak dari pembangunan infrastruktur yang berbasis IT, Serta masyarakat juga merasakan kepraktisan dari pada penggunaan aplikasi Jogja Smart Service tersebut. Pemerintah Kota Yogyakarta khususnya Dinas komunikasi Informasi dan Persandian Kota Yogyakarta sangat berperan aktif dalam meningkatkan pelaksanaan smart city di Kota Yogyakarta berupa Jogja Smart Service.

Pelaksanaan smart city di Kota Yogyakarta sangat didukung oleh Pemerintah dengan berbagai macam 
fasilitas penunjang seperti penyediaan wifi di 100 titik poin. Hal tersebut sangat membantu keberhasilan pelaksanaan Jogja Smart Service untuk digunakan oleh masyarakat Kota Yogyakarta. Pemerintah Kota Yogyakarta bekerja sama dengan Dinas Komunikasi Informasi dan Persandian Kota Yogyakarta dalam mengatasi hambatan masyarakat yang belum 100 persen terbuka dengan teknologi pemerintah sudah menyiapkan media akses smart city di dinas atau unit kerja terkait dengan menyediakan komputer dan admin yang akan membantu masyarakat dalam mengoperasikan aplikasi. Hal ini bertujuan untuk mengenalkan terlebih dahulu bahwa dengan perkembangan teknologi smart city masyakart Kota Yogyakarta akan lebih mudah, lebih cepat dan sangat efisien dalam pengurusan yang terkait dengan pemerintahan.

\section{DAFTAR PUSTAKA}

Ainul Yaqin. 2005. "Pendidikan Multikultural". Yogyakarta : Pilar Media.

Binti Munah. 2009. "Landasan Pendidikan”. Yogyakarta : Teras.

Budi Winarno. 2014. "Kebijakan Publik." Yogyakarta : Caps.

Burhan Bungin. 2007. "Analisis Data Penelitian Kualitatif”. Jakarta : Raja Grafindo Persada.

H.A.R Tilaar. 2002. "Pendidikan, Kebudayaan dan Masyarakat Madani Indonesia”. Bandung :

Remaja Rosda Karya.

Husaini Usman \& Purnomo Setiady Akbar. 2000. "Metodelogi Penelitian Sosial”. Jakarta : Bumi Aksara.

I Putu Agus Eka Pratama. 2014. "Smart City Beserta Cloud Computing \& Teknologi-teknologi

Pendukung Lainnya". Bandung : Informatika Bandung.

Lexy J.Moleong. 2000. "Metode Penelitian Kualitatif”. Bandung : Remaja Rosda Karya.

Moekijat. "Analisis Kebijakan Publik". 1995. Bandung : Mandar Maju.

Nurgiansah, T. H. (2019). Pemutakhiran Kurikulum Pendidikan Kewarganegaraan di Era Revolusi Industri 4.0. Prosiding Seminar Kewarganegaraan Universitas Negeri Medan, 1(1), 95-102.

Ridwan \& Sudrajat. 2009. “Manajemen Pemerintahan Dalam Prespektif Pemerintah Kota Yogyakarta dan Masyarakat Kota Yogyakarta. Pelayanan Publik”. Jakarta : Pustaka Pelajar.

Samsudin. 2017. "Sosiologi Perkotaan, Studi Perubahan Sosial dan Budaya". Bengkulu : Pustaka Pelajar.

Sugiyono. 2010. "Metode Penelitian Pendidikan Pendekatan Kuantitatif, Kulaitatif, dan R \& D". Bandung. Alfabeta.

Suharsimi Arikunto. 2010. "Metode Penelitian Suatu Pendekatan Praktek". Jakarta : Rineka Cipta.

Sulasman \& Setia Gumilar. 2013. “Teori-Teori Kebudayaan”. Bandung : Pustaka Setia. 